\title{
NUMERICAL SIMULATION OF DISSIMILAR WELD JOINT IN SYSWELD SIMULATION SOFTWARE
}

\author{
Radoslav Koňár, Marek Patek
}

Original scientific paper

Dissimilar weld joints are prone to frequent failures caused by many factors. Several methods might be used for prediction of the failures, from which prediction of the residual stresses and weld joint hardness plays a very important role. During the construction design, there is a possibility to predict residual stress by welding numerical simulation that may serve as the failure prevention. In presented article, residual stresses of dissimilar X5CrNi1810/S355J2H weld joint were predicted by SYSWELD software after optimization of welding process by experimentally obtained thermal behaviour. The hardness wizard tool of the programme was employed for prediction of the weld joint hardness.

Keywords: dissimilar weld; hardness prediction; residual stress; SYSWELD; temperature field

\section{Numerička simulacija zavarenog spoja od različitih materijala u simulacijskom programu SYSWELD}

Izvorni znanstveni članak

Zavareni spojevi od različitih materijala podliježu čestim kvarovima zbog raznih faktora. Postoji nekoliko metoda koje se mogu primijeniti za predviđanje kvarova, a među njima vrlo važnu ulogu ima predviđanje zaostalih naprezanja i tvrdoće zavara. Tijekom dizajniranja konstrukcije, postoji mogućnost predviđanja zaostalog naprezanja numeričkom simulacijom varenja koja može služiti za prevenciju kvara. U ovom radu zaostala naprezanja zavarenog spoja X5CrNi18-10/S355J2H od različitih materijala predviđena su programom SYSWELD nakon optimizacije postupka zavarivanja eksperimentalno dobivenim toplinskim ponašanjem. Čudesni alat za tvrdoću iz tog programa upotrjebljen je za predviđanje tvrdoće zavarenog spoja.

Ključne riječi: predviđanje tvrdoće; SYSWELD; temperaturno područje; zaostalo naprezanje; zavar od različitih materijala

\section{Introduction}

Dissimilar metal weld joints are widely used in the nuclear power plants to connect the ferritic steel components and the austenitic steel piping systems [1]. Components of the power plants steam generators operating at high temperatures are made of stainless (austenitic) steels and components that operate at lower temperatures are made of ferritic steels [2].

The dissimilar metals joints are prone to frequent failures and these failures are generally attributed to one or more of the following causes: (a) difference in mechanical properties across the weld joint and coefficients of thermal expansion (CTE) of the two types of steels (CTE for austenitic and ferritic steel are typically 18 and $14 \times 10^{-6} / \mathrm{K}$, respectively) and the resulting creep at the interface, (b) general alloying problems of the two different base metals such as brittle phase formation and dilution, (c) carbon migration from the ferritic steel into the stainless steel, which weakens the heat affected zone (HAZ) in the ferritic steel, (d) preferential oxidation at the interface, (e) residual stresses present in the weld joints, (f) service conditions and other factors etc. [2]. The presence of residual stresses can be detrimental to the performance of the welded product. Tensile residual stresses are generally detrimental, increasing the susceptibility of a weld to fatigue damage, stress corrosion cracking and fracture [3].

Recently, a number of the numerical simulation

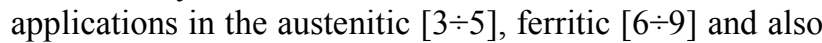
dissimilar weld joints welding $[1,10 \div 12]$ has been presented. Numerical simulation offers an opportunity to predict residual stresses of the weld joint that are essential for the quality and the lifetime of dissimilar weld joints.

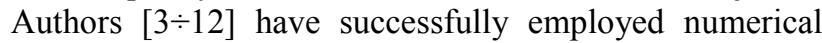
simulation with results well corresponding with experimental measures. The crucial conditions are employing the temperature-dependent material properties and good coincidence of temperature distribution during welding. Residual stresses of the weld joint can be thus predicted when the material properties are well determined and thermal behaviour (thermal cycles) well corresponding with experimental measures.

In this article, residual stresses of dissimilar weld joint of ferritic S355J2H and austenitic X5CrNi18-10 steel are predicted by numerical simulation of welding. Hardness of weld joint is predicted as well and compared to experimental hardness results.

\section{Methodology of experiments and numerical simulation input parameters}

Materials used in this study are austenitic X5CrNi1810(AISI 304) and ferritic S355J2H steel pipes with outer diameter of $60,3 \mathrm{~mm}$, thickness of $4 \mathrm{~mm}$ and length of $115 \mathrm{~mm}$. Weld joint has been prepared by gas tungsten arc welding (GTAW) method. The filler material was austenitic welding wire OK Tigrod 309 LSi (W 2312 LSi) with $2,5 \mathrm{~mm}$ diameter. Welding conditions are shown in Tab. 1. Weld joint was made by two weld passes.

Table 1 Welding parameters

\begin{tabular}{|c|c|c|c|c|}
\hline $\begin{array}{c}\text { Welding } \\
\text { pass }\end{array}$ & $\begin{array}{c}\text { Welding } \\
\text { current } \\
I(\mathrm{~A})\end{array}$ & $\begin{array}{c}\text { Arc voltage } \\
U(\mathrm{~V})\end{array}$ & $\begin{array}{c}\text { Welding } \\
\text { speed } \\
v(\mathrm{~mm} / \mathrm{s})\end{array}$ & $\begin{array}{c}\text { Heat input } \\
P(\mathrm{~J} / \mathrm{cm})\end{array}$ \\
\hline 1 & 85 & 10 & 1,5 & 3400 \\
\hline 2 & 85 & 10 & 1,35 & 3778 \\
\hline
\end{tabular}

During the experiment, temperature distribution was measured by four thermocouples. Location of the thermocouples and preparation of weld edges before welding are shown in Fig. 1a. Welding was done at the 
$\mathrm{PH}$ welding position (welding upwards on the pipe) according to welding directions shown in Fig. $1 \mathrm{~b}$. Welding setup is shown in Fig. 2. After welding, macrostructural analysis of weld joint was performed. Macrograph of the weld joint together with welding conditions then served to configure parameters of heat input to the numerical simulation. Hardness of the weld joint was evaluated by Vickers testing method (HV10) in terms of EN ISO 9015-1 standard.

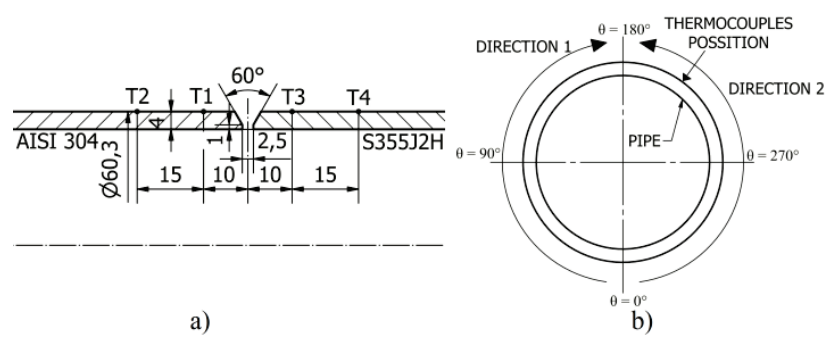

Figure 1 Experimental conditions: a) weld joint preparation and position of the thermocouples and b) welding direction

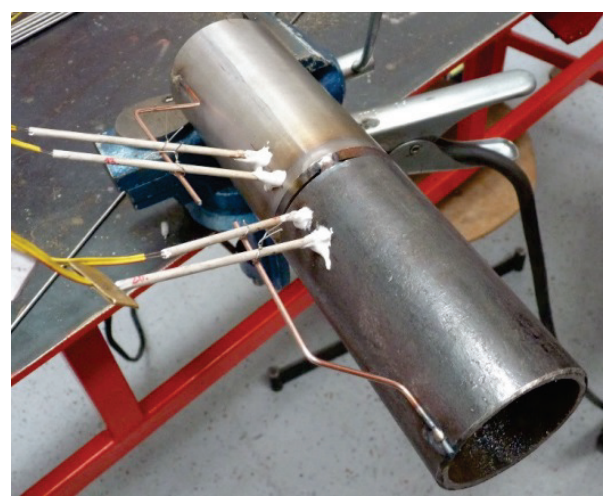

Figure 2 Dissimilar tube welding setup

Based on the weld joint geometry and pass sequence, the finite element (FE) model of the weld joint was developed (Fig. 3) by using Visual Mesh software. 3D FE model was developed to obtain a high accuracy of predicted residual stresses. Welding simulation was computed by SYSWELD software. In the software, welding phenomenon is divided into thermal and mechanical analysis.

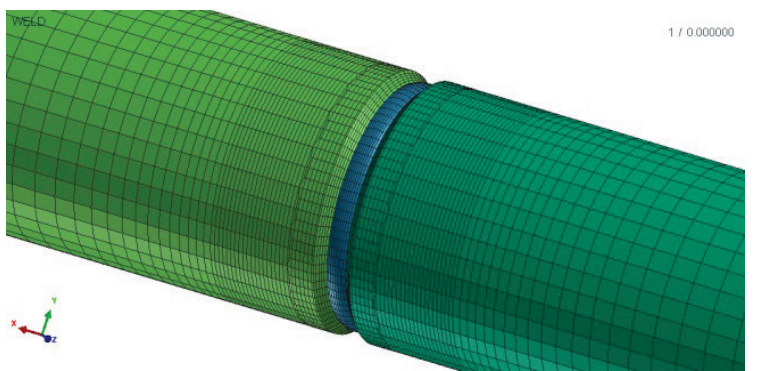

Figure 3 Finite element model of weld joint

Thermal analysis is based on the heat transfer in solids described by the heat Eq. (1):

$$
\begin{aligned}
& \rho \cdot \frac{\mathrm{d} H}{\mathrm{~d} t}-\operatorname{div}(\lambda \cdot \operatorname{grad} T)-Q=0 \\
& \lambda \cdot \operatorname{grad} T \cdot n=q(t, T) \text { on } \partial \Omega_{q}, \\
& T=T_{\mathrm{p}}(t) \text { on } \partial \Omega_{T},
\end{aligned}
$$

$\partial \Omega=\partial \Omega_{q} \cup \partial \Omega_{T} x$

where $\rho, H, \lambda$ and $T$ are density, enthalpy, thermal conductivity and temperature, respectively. In Eq. (1), $Q$ represents an internal heat source. In Eq. (2), $n$ is the outward normal vector of domain $\partial \Omega$ and $q$ is the heat flux density that can depend on temperature and time to model radiative and convective heat exchanges on the surface. $T_{\mathrm{p}}$ represents the prescribed temperature [4]

As the internal heat source, the double ellipsoidal heat source proposed by Goldak was employed in the simulation. General equation of heat source for front and rear ellipsoid is given by Eq. (5):

$Q_{\mathrm{f}, \mathrm{r}}(x, y, z, t)=\frac{6 \cdot \sqrt{3} \cdot f_{\mathrm{f}, \mathrm{r}} \cdot Q_{\mathrm{w}}}{a_{\mathrm{f}, \mathrm{r}} \cdot b \cdot c \cdot \pi \cdot \sqrt{\pi}} \cdot \mathrm{e}^{\frac{-3 \cdot x^{2}}{a_{\mathrm{f}, \mathrm{r}}^{2}}} \cdot \mathrm{e}^{\frac{-3 \cdot y^{2}}{b^{2}}} \cdot \mathrm{e}^{\frac{-3 \cdot z^{2}}{c^{2}}}$

where $x, y$ and $z$ are the local coordinates of the double ellipsoid model aligned with the welded pipe; $f_{\mathrm{f}}$ and $f_{\mathrm{r}}$ are parameters which give the fraction of the heat deposited in the front and the rear parts, respectively. $Q_{\mathrm{w}}$ is the power of the welding heat source (heat input in Tab. 1). It can be calculated according to the welding current, the arc voltage and the arc efficiency. The parameters $a_{\mathrm{f}}, a_{\mathrm{r}}, b$ and $c$ are related to the characteristics of the welding heat source.

Parameters of double-ellipsoidal heat source defined according to macrograph from the experiment and welding conditions are shown in Tab. 2. Parameters of each weld bead were defined in such way that dimensions of the melted area in the simulation were the same as weld bead dimensions (Fig. 4).

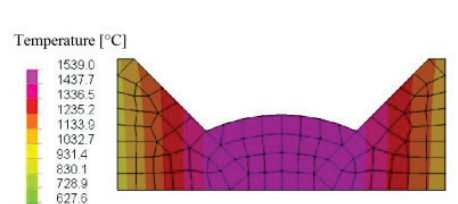

1st pass

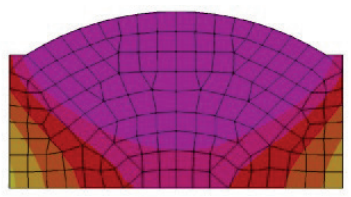

2nd pass

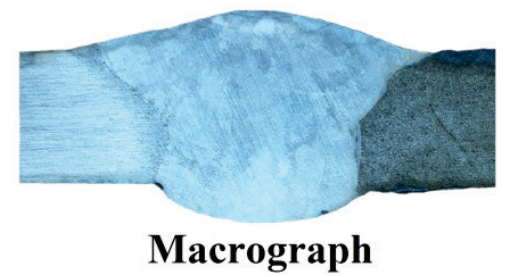

Figure 4 Thermal fields after simulation compared to weld macrograph

Material properties of ferritic steel were used from the material database of S355J2G3 material, which correspond to experimental ferritic steel. Applied material database does not contain $\mathrm{X} 5 \mathrm{CrNi} 18-10$ material properties, but X2CrNiMo17-12-2 (AISI 316L) material is present. Comparison of the thermal and mechanical properties (for example thermal conductivity in Fig. 5 and Yield stress in Fig. 6) shows very similar values and the database of X2CrNiMo17-12-2 steel can be thus used to simulate austenitic material behaviour. Filler material properties were also defined by material database of X2CrNiMo17-12-2 steel. 
Table 2 Parameters of the heat source for each pass

\begin{tabular}{|c|c|c|c|c|c|c|c|c|c|c|}
\hline Pass & $Q_{\mathrm{f}} / \mathrm{W} / \mathrm{mm}^{3}$ & $Q_{\mathrm{r}} / \mathrm{W} / \mathrm{mm}^{3}$ & $a_{\mathrm{f}} / \mathrm{mm}$ & $a_{\mathrm{r}} / \mathrm{mm}$ & $b / \mathrm{mm}$ & $c / \mathrm{mm}$ & $x_{0} / \mathrm{mm}$ & $a_{y} /{ }^{\circ}$ & $y_{0} / \mathrm{mm}$ & $z_{0} / \mathrm{mm}$ \\
\hline 1. & 8,645 & 6,5 & 2 & 4 & 3 & 3,8 & 0 & 0 & 0 & -1 \\
\hline 2. & 21,945 & 16,5 & 2 & 4 & 5 & 0,9 & 0 & 0 & 0 & -4 \\
\hline
\end{tabular}

Table 3 Peak temperatures $\left({ }^{\circ} \mathrm{C}\right)$ in places of thermocouples locations after numerical simulation and experiment

\begin{tabular}{|c|c|c|c|c|c|c|}
\hline Pass & Direction & FEM/Exp. & T1 & T2 & T3 & T4 \\
\hline 1 & 1 & Exp. & 264,2 & 184,8 & 268,9 & 214,4 \\
\hline 1 & 1 & FEM & 159,0 & 125,9 & 134,3 & 92,8 \\
\hline 1 & 2 & Exp. & 864,8 & 395,9 & 624,0 & 376,3 \\
\hline 1 & 2 & FEM & 714,3 & 310,4 & 673,7 & 251,0 \\
\hline 2 & 1 & Exp. & 707,5 & 402,3 & 507,1 & 367,2 \\
\hline 2 & 1 & FEM & 256,9 & 221,6 & 235,3 & 181,5 \\
\hline 2 & 2 & Exp. & 887,2 & 474,1 & 715,6 & 447,1 \\
\hline 2 & 2 & FEM & 909,2 & 408,7 & 834,1 & 360,0 \\
\hline
\end{tabular}

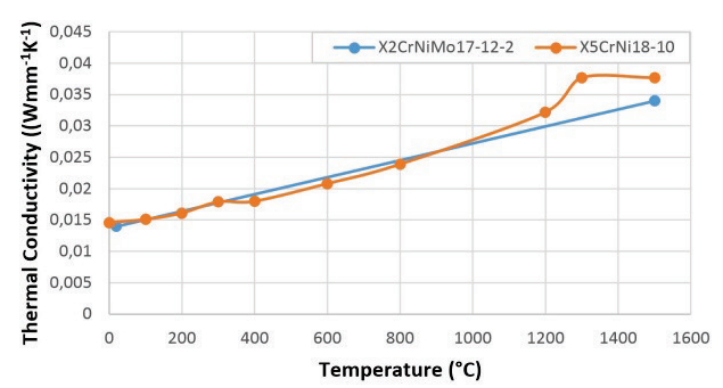

Figure 5 Comparison of time dependent thermal conductivity of X5CrNi18-10 and X2CrNiMo17-12-2 steel [3, 14]

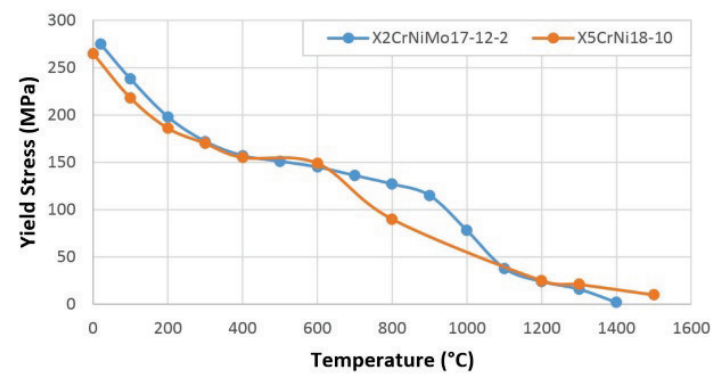

Figure 6 Comparison of time dependent Yield strength of X5CrNi18-10 and $\mathrm{X} 2 \mathrm{CrNiMo17-12-2}$ steel [3, 14]

The mechanical analysis is based on the usual equations describing the static equilibrium. Theoretical background for the mechanical analysis of welding simulation and equations employed by SYSWELD are described in [14]. During the mechanical analysis, phase transformation of the ferritic steel is taken into account together with temperature dependent material properties.

Based on thermal and mechanical analysis results, hardness of weld joint can be computed. Hardness Wizard computational module was employed to compute Vickers hardness (HV10) of the weld joint. For materials with carbon level below 0,5\%, Maynier calculation Eq. (6) is applied [15].

$H V=\frac{\% F P \cdot H V_{F-P}+\% B \cdot H V_{B}+\% M \cdot H V_{M}}{100}$

where $\% F P, \% B$ and $\% M$ are volume fractions of the ferrite and perlite, bainite and martensite, respectively. $H V_{F-P}, H V_{B}$ and $H V_{M}$ are values of the hardness for material constituents, which can be computed by Eqs. (7) to $(9)[15,16]$.
$H V_{M}=127+949 \mathrm{C}+27 \mathrm{Si}+11 \mathrm{Mn}+16 \mathrm{Cr}+8 \mathrm{Ni}+21 \cdot \log v_{\mathrm{R}}(7)$

$H V_{B}=-323+185 \mathrm{C}+330 \mathrm{Si}+153 \mathrm{Mn}+144 \mathrm{Cr}+191 \mathrm{Mo}+65 \mathrm{Ni}+$

$+\left(\log v_{\mathrm{R}}\right) \cdot(89+53 \mathrm{C}-55 \mathrm{Si}-22 \mathrm{Mn}-20 \mathrm{Cr}-33 \mathrm{Mo}-10 \mathrm{Ni})$

$H V_{F-P}=42+223 \mathrm{C}+53 \mathrm{Si}+30 \mathrm{Mn}+7 \mathrm{Cr}+19 \mathrm{Mo}+12,6 \mathrm{Ni}+$

$+\left(\log v_{\mathrm{R}}\right) \cdot(10-19 \mathrm{Si}+8 \mathrm{Cr}+4 \mathrm{Ni}+130 \mathrm{~V})$

where $v_{\mathrm{R}}$ is cooling rate and $\mathrm{C}, \mathrm{Si}, \mathrm{Mn}, \mathrm{Cr}, \mathrm{Mo}, \mathrm{Ni}, \mathrm{V}$ represent mass concentrations of the alloying elements. Chemical composition, cooling rate and volume fractions of the material phases to the hardness computing were used from database of materials and results of the thermal analysis.

\section{Results}

Thermal cycles obtained by experimental measures and numerical simulation are shown in Fig. 7 and 8, respectively. Peak temperatures during welding after experiment and simulation of each pass at each direction are shown in Tab. 2.

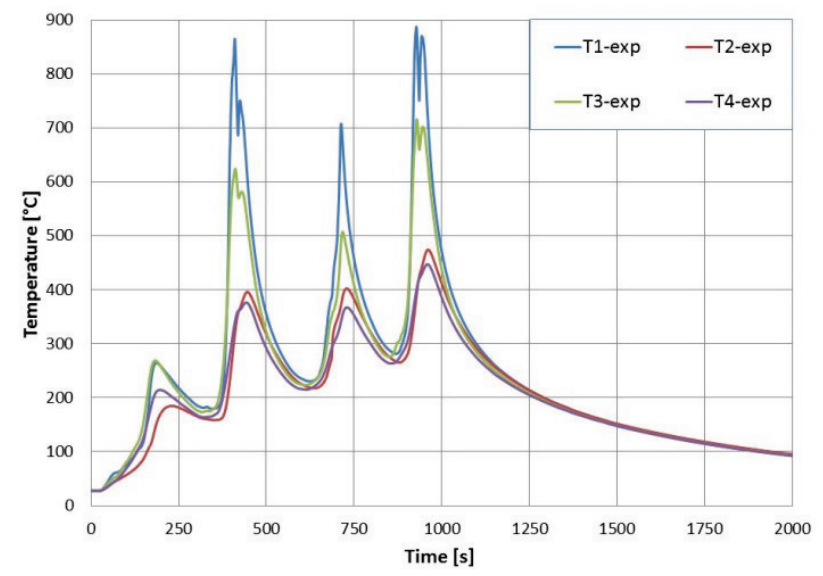

Figure 7 Thermal cycles from experimental measures

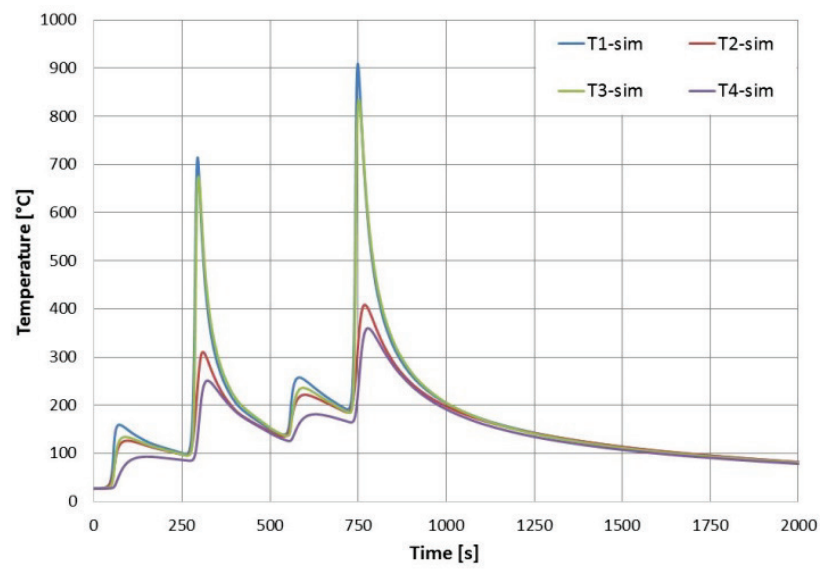

Figure 8 Thermal cycles from numerical simulation

The peak temperatures of the first welding direction are evidentially lower in simulation compared to experimental results. Differences between simulated and 
experimental results might be caused by crossing the $\theta$ angle of $180^{\circ}$ during the experiment that leads to decreasing the distance of electric arc and thermocouples. Lower distance between thermocouples and weld pool rapidly increased measured temperature. On the other side, there is a good agreement between the peak temperatures of the second weld direction, which is better for comparison because measured place crosses the thermocouples location. Good agreement can be also observed on cooling behaviour of the materials measured by thermal cycles and simulation.

Results of thermal analysis were the basement of mechanical analysis of dissimilar pipe welding. As the thermal results have been approved by experiment, it is possible to predict mechanical behaviour of weld according to thermal analysis result and temperature dependent mechanical properties of base materials. Residual stresses of the weld joint in the different circumferential angles are shown in Figs. 9 $\div 10$.

Fig. 9 shows the axial residual stresses on the outer plane in the circumferential angles of $0^{\circ}, 90^{\circ}, 180^{\circ}$ and $270^{\circ}$, respectively. Maximal compressive axial residual stress predicted by numerical simulation is in the circumferential angle of $270^{\circ}$ and maximal tensile axial stress is in the angle of $90^{\circ}$. Maximal compressive axial stresses in some cases exceeded minimal value of the base metal yield stress $(230 \mathrm{MPa})$. This residual stress increasing occurs in the distance from weld centreline of 4,5 to $10 \mathrm{~mm}$ on the austenitic side of weld joint.

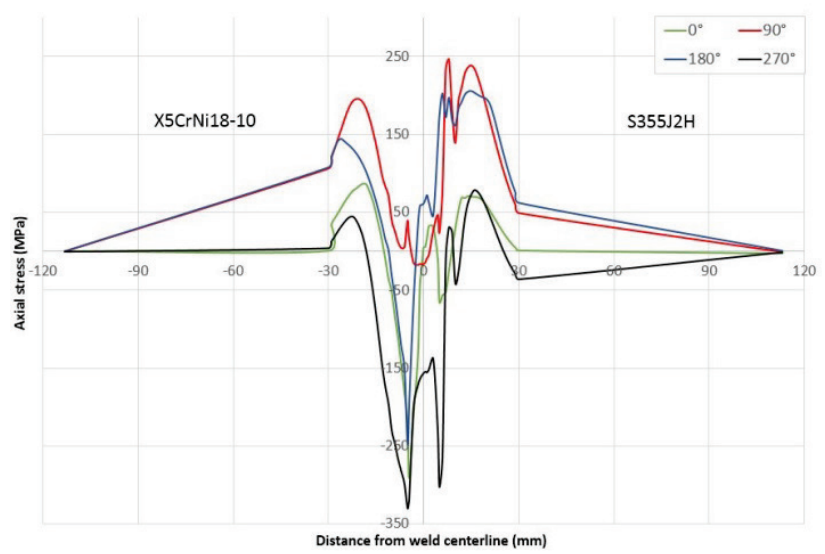

Figure 9 Axial residual stress in different circumferential angle

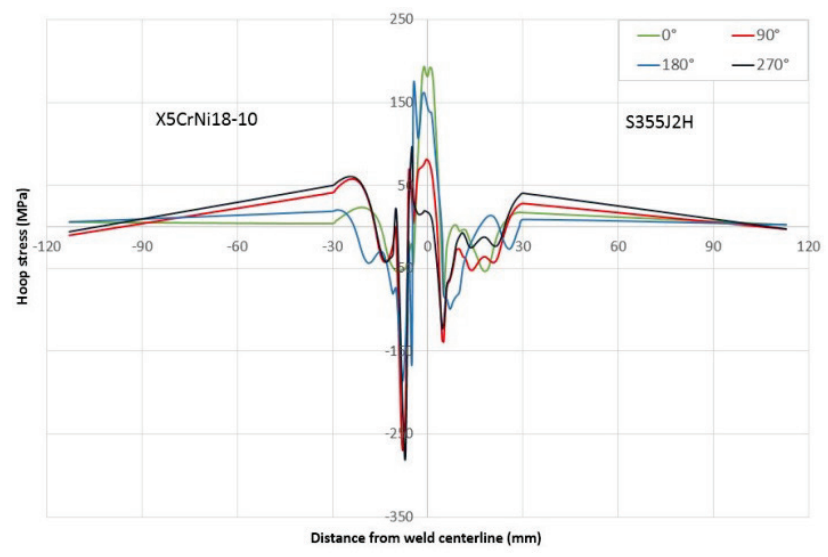

Figure 10 Hoop residual stress in different circumferential angle

Hoop stresses (Fig. 10) have also maximal compressive value in the angle of $270^{\circ}$. Maximal tensile hoop stress on the outside plane was predicted by simulation in the angle of $0^{\circ}$. Similarly to axial residual stress, compressive hoop stresses on the austenitic side have in the distance range of $7 \div 8 \mathrm{~mm}$ from the weld axis higher values than base metal yield stress.

Vickers hardness values after measuring and numerical simulation are shown in Fig. 11 (hardness of the face side of the weld) and Fig. 12 (hardness in the root of the weld). It can be seen that Vickers hardness of weld metal and HAZ is after simulation higher as in the experiment for both face and root of the weld. Maximal hardness of weld on the face and root side is in the austenitic base metal with the value of $221 \mathrm{HV}$ (face) and $211 \mathrm{HV}$ (root) and after simulation is maximal hardness in the HAZ of the ferritic steel $(223 \mathrm{HV}$ - face and 281 HV root).

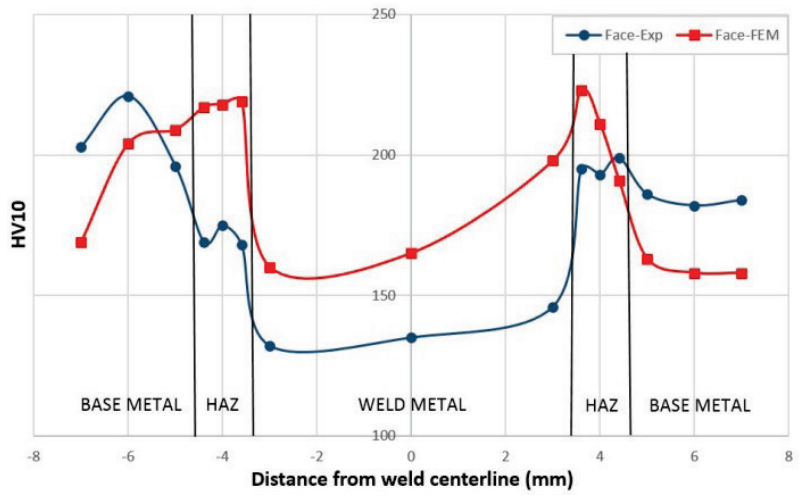

Figure 11 Vickers hardness on the face side of the weld

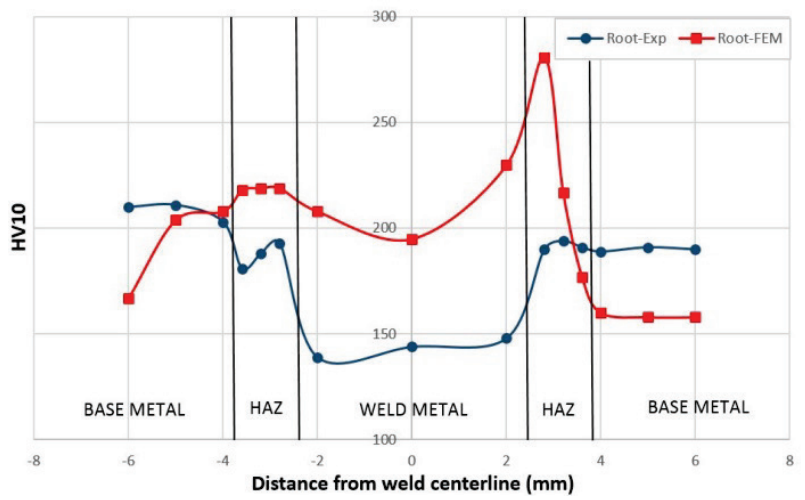

Figure 12 Vickers hardness on the root side of the weld

\section{Discussion}

In this study, the 3D numerical simulation of the dissimilar weld joint in SYSWELD software is presented. To compare numerical and experimental temperature behaviour the most appropriate are peak temperatures together with the shape of the thermal cycles. Peak temperatures of the two weld beads made in two directions show some differences. These differences occur mainly in the first welding direction. It is probably due to exceeding of circumferential angle $\theta=180^{\circ}$ by welder during experiment, what might lead to reducing the distance between weld pool and the thermocouples and to rapidly increased temperature. Peak temperatures measured during the welding in the second direction have significantly lower differences. These peak temperatures are more preferable for comparison of experimental and 
simulation results because the measuring plane (crosssection of the pipes in the place of thermocouples) crosses the weld pool trajectory. Peak temperature differences and shape of the thermal cycles are in good agreement with dissimilar weld joint simulation results of KumarKrishnasamy [10]. Present differences of the measured and simulated peak temperatures might be caused by some differences between properties of X5CrNi18-10 and $\mathrm{X} 2 \mathrm{CrNiMo17-12-2}$ steel while the former was used in the experiment and the properties of the latter in the simulation. Also some of the authors [3, 5, 12, 13] recommend application of artificially increased thermal conductivity (three times larger than value at the room temperature) to account for heat transfer due to fluid flow in the weld pool. This recommendation was not used in the numerical simulation either, what might lead to presence of discrepancies.

Residual stresses in axial and tangential (hoop) direction referred to the possibility of excessing the base material yield stress. This fact might lead to deformations of welded pipes and it should be taken into account at the construction design. Distribution and range of the axial and hoop residual stresses show good agreement with the works of Deng [3, 5], which are compared to experimental measures by strain gauges. There can be seen that higher residual stresses are present on the austenitic side of the welds.

Vickers hardness of the weld joint after simulation reached higher values in the weld metal and HAZ. The reason might be application of the filler material with low carbon content $(<0,03$ wt. \%) during the experiment with properties appropriate to welding of dissimilar welds. During simulation, the properties of X2CrNiMo17-12-2 austenitic steel have been employed because of low accessibility of filler material time depending properties, which do not have to exactly correspond with filler material properties. Vickers hardness in both simulation and experiment does not reach values of brittle phases (such as martensite or bainite) formation (over $300 \mathrm{HV}$ ) $[17,18]$ so the FE modelling of welding process brings the sufficient prediction of weld joint hardness.

\section{Conclusion}

Welding simulation of dissimilar weld joints is an effective tool to predict thermal behaviour, residual stresses and hardness of the weld joint. Several conclusions can be stated from the results of $\mathrm{FE}$ simulation of austenitic $\mathrm{X} 5 \mathrm{CrNi18}-10$ and ferritic S355J2H steel as follows:

1) Peak of the axial and hoop residual stresses in the weld area can reach higher values than yield stress of parent material, especially on the austenitic side of the weld joint.

2) Unbalanced distribution of the residual stress occurs in the weld joint vicinity of $\mathrm{X} 5 \mathrm{CrNi18}-10$ and S355J2H weld joint with higher values on the austenitic side.

3) Maximal compressive hoop and the axial stress are located in the circumferential angle of $270^{\circ}$.

4) Tensile stress reached the maximum values of axial and hoop direction in the circumferential angle of $90^{\circ}$ and $0^{\circ}$, respectively.
5) Vickers hardness after the simulation and experiment did not reach the values of hard and brittle phase formation on the ferritic steel side.

\section{Acknowledgements}

This work has been supported by Scientific Grant Agency of Ministry of Education of the Slovak Republic, grant KEGA 034ŽU-4/2015. Authors acknowledge the grant agency for support.

\section{References}

[1] Deng, D. et al. Prediction of residual stresses in a dissimilar metal welded pipe with considering cladding, buttering and post weld heat treatment. // Computational Materials Science. $\quad 47(2009), \quad$ pp. 398-408. DOI: 10.1016/j.commatsci.2009.09.001

[2] Joseph, A. et al. Evaluation of residual stresses in dissimilar weld joints. // International Journal of Pressure Vessels and Piping. 82(2005), pp. 700-705. DOI: 10.1016/j.jpvp.2005.03.006

[3] Deng, D.; Murakawa, H. Numerical simulation of temperature field and residual stress in multi-pass welds in stainless steel pipe and comparison with experimental measurements. // Computational Materials Science. 37(2006), pp. 269-277. DOI: 10.1016/j.commatsci.2005.07.007

[4] Duranton, P. et al. 3D modelling of multipass welding of a 316L stainless steel pipe. // Journal of Materials Processing Technology. 153-154(2004), pp. 457-463. DOI: 10.1016/j.jmatprotec.2004.04.128

[5] Deng, D.; Murakawa, H.; Liang, W. Numerical and experimental investigations on welding residual stress in multi-pass butt-welded austenitic stainless steel pipe. // Computational Materials Science. 42(2008), pp. 234-244. DOI: 10.1016/j.commatsci.2007.07.009

[6] Wang, Y. et al. Simulation and analysis of temperature field for in-service multi-pass welding of a sleeve fillet weld. // Computational Materials Science. 68(2013), pp. 198-205. DOI: 10.1016/j.commatsci.2012.10.025

[7] Žmindák, M.; Meško, J.; Pelagic, Z.; Zrak, A. Finite Element Analysis of Crack Growth in Pipelines. // Manufacturing Technology. 14, 1(2014), pp. 116-122.

[8] Novák, P.; Meško, J.; Žmindák, M. Finite element implementation of Multi-pass Fillet Weld with Phase Changes. // Manufacturing Technology. 13, 1(2013), pp. 79-85.

[9] Moravec, J. Influence of Welding Parameters on Weld Pool's Geometry in Shielding Gas Welding. Pollypress, Liberec, 2011.

[10] Kumar-Krishnasamy, R.; Siegele, D. 3D modelling of a multi pass dissimilar tube welding and post weld heat treatment of nickel based alloy and chromium steel. // International Journal of Pressure Vessels and Piping. 87(2010), pp. 643-649. DOI: 10.1016/j.jpvp.2010.08.010

[11] Akbari, D.; Sattari-Far, I. Effect of the welding heat input on residual stresses in butt-welds of dissimilar pipe joints. // International Journal of Pressure Vessels and Piping. 86(2009), pp. 769-776. DOI: 10.1016/j.jppp.2009.07.005

[12] Lee, Ch.-H.; Chang, K.-H. Comparative study on girth weld-induced residual stresses between austenitic and duplex stainless steel pipe welds. // Applied Thermal Engineering. 63(2014), pp. 140-150. DOI: 10.1016/j.applthermaleng.2013.11.001

[13] Asl, H. M.; Vatani, A. Numerical analysis of the burnthrough at in-service welding of 316 stainless steel pipeline. // International Journal of Pressure Vessels and Piping. 105106(2013), pp. 49-59. DOI: 10.1016/j.jppv.2013.03.002 
[14] SYSWELD Engineering Guide of Training and Toolbox. France : ESI Group, 2006.

[15] Meynier, P.; Dollet, J.; Bastien, P. Creusot-Loire System for the prediction of the mechanical properties of low alloy steel products. // Hardenability concepts with applications to steel / Sheraton, 1977, pp. 518-545.

[16] Trzaska, J. Calculation of the steel hardness after continuous cooling. // Archives of Materials Science and Engineering. 61, 2(2013), pp. 87-92.

[17] Dopjera, D.; Mičian, M.; Sládek,A. Phased Array System for non destructive testing in the industry. // Advanced manufacturing and repairing technologies in vehicle industry, $30^{\text {th }}$ international colloquium / Budapest, Hungary, 2013, pp. 103-110.

[18] Radek, N; Bartkowiak, K. Laser Treatment of ElectroSpark Coatings Deposited in the Carbon Steel Substrate with using Nanostructured WC-Cu Electrodes. // Physics Procedia. 39(2012), pp. 295-301. DOI: 10.1016/j.phpro.2012.10.041

\section{Authors' addresses}

Radoslav Koňár, Ing., PhD.

University of Žilina, Faculty of Mechanical Engineering, Department of Technological Engineering

Univerzitná 1, 01026 Žilina, Slovakia

radoslav.konar@fstroj.uniza.sk

\section{Marek Patek, Ing.}

University of Žilina, Faculty of Mechanical Engineering,

Department of Technological Engineering

Univerzitná 1, 01026 Žilina, Slovakia

marek.patek@fstroj.uniza.sk 